\title{
Foreword by the Editor
}

Tim Pringle

As incoming Editor, I decided to postpone my first foreword in The China Quarterly until the third issue on my watch. The aim was to maintain a sense of continuity via a quiet - and, dare I say it, largely unnoticed - period of transition. Given the continued excellent health of the journal, both this foreword and acknowledgements of my predecessor's work could wait until a smooth handover had been achieved. We nearly made it!

The tumultuous events of late July and August, during which access in China to over 300 articles and book reviews published in the Quarterly were blocked and then unblocked by Cambridge University Press (CUP), disrupted somewhat the drafting of my foreword. While the issues of censorship and academic freedom in relation to research and publishing in China remain far from resolved, CUP's demonstrable willingness to work with us to maintain access to The China Quarterly in a challenging regulatory environment has allowed a brief pause for reflection - and a foreword from the Editor.

First, I must acknowledge the achievements of my predecessor Chris Bramall. Chris brought the rigour and authority of his own research to his role as Editor of the Quarterly and the results have been clear. Under his leadership, the journal consolidated its position at the top of the China area studies tree whether measured by number of citations or other forms of impact. His time as Editor was not short on debate during which strongly held views on the direction of the journal were aired. And quite right too, especially given the recent episode of censorship. The bottom line, however, did not change: The China Quarterly continued to publish top-quality and original scholarship derived from an expanding number of submissions that has generated new knowledge of China. It is a legacy I will work very hard to build on.

The journal's ongoing success is a team effort. Our position is the result of the superb work of the editorial managers Raphael Jacquet and Rowan Pease and copy-editors Joanne Phillips and Rosemary Williams. The time and expertise given by members of the Executive Committee and Editorial Board continue to underpin The China Quarterly's reputation for excellence and I look forward to strengthening relations with both bodies. And of course, none of this would happen without the research, manuscripts and peer reviews from authors and academics working on China.

Let me now turn to the core issues of academic freedom in general and censorship of articles in particular. As I have repeatedly stated in the media and in statements on The China Quarterly website, we will not condone curtailments of academic freedom whether imposed via external censorship or forms of selfcensorship. While The China Quarterly team strongly disagrees with attempts by governments to censor the outcome of academic research, we cannot violate sovereign laws or regulations. But my first responsibility is to The China 
Quarterly's community of scholars that have made the journal what it is today. Not to some of you, not to the majority of you - but to all of you. Drawing on the expertise and support of the Executive Committee, Editorial Board and CUP, I will strive to demonstrate this commitment in the challenges and changes that lie ahead.

The challenges facing Xi Jinping's government are the outcomes of accumulated successes and failures. They exist in an interconnected global environment that both changes and is changed by China. The task facing China area studies is to research and theorize the processes and policies driving these outcomes by critically engaging with the existing literature and analysing original primary data. The Quarterly will continue to publish manuscripts that address aspects of China's governance and politics, and encourages submissions focusing on the country's "going out" (zou chuqu 走出去) policies.

The Quarterly receives significant numbers of manuscripts that rely on quantitative research methods and we will continue to publish the very best of them. Conversely, the space for conducting qualitative research is narrowing just as the importance of collective agency to governance in China is growing. In fact, policy innovation is often catalyzed by the various "movements" of those on the wrong side of China's economic success. Indeed, the concept of upholding rights (weiquan 维权) is now part of the official lexicon and academic discourse. I will therefore welcome manuscripts that demonstrate innovation in qualitative research methods grounded in relevant academic disciplines and able to generate new knowledge of economic, political and social relations across China.

In sum: continuity and adaptation to a changing environment. My priorities are to build on The China Quarterly's reputation in China area studies; encourage innovative research that rises to emerging opportunities and constraints; and develop scholarship on China's role in the world. Finally, lest there be any confusion, high-quality articles will continue to be warmly received by the Quarterly, irrespective of the subject matter they address. 